\title{
Nitrogenase Model Reaction: Electron-Transfer Reduction of Phenylacetylene and Azobenzene by Catalysis of Copolypeptide-Molybdenum Complexes in Protic Solvent
}

\author{
Nobuki OGuni, Shogo ShimazU, and Akira NAKAMURA \\ Department of Macromolecular Science, Faculty of Science, Osaka University, \\ 1-1 Machikaneyama, Toyonaka, Osaka 560, Japan.
}

(Received June 21, 1980)

\begin{abstract}
Novel thioxanthate molybdenum complexes supported on copolypeptides consisting of L-cysteine and $\gamma$-benzyl L-glutamate were prepared and the catalysis for the reduction of phenylacetylene and azobenzene with sodium borohydride was investigated as nitrogenase model reaction. A binary catalytic system consisting of polypeptide-molybdenum complexes and the ferredoxin model complex was found to be superior to that of the corresponding unsupported molybdenum complex.
\end{abstract}

KEY WORDS Nitrogenase Model Reaction / Molybdenum Complex / Ferredoxin Model Complex / Copolypeptide of L-Cysteine and $\gamma$-Benzyl LGlutamate / Reduction of Phenylacetylene and Azobenzene /

Investigations on the active center of nitrogenase have been carried out in the last few years. Very recently, Shah and Brill reported the isolation of an "iron-molybdenum cofactor (Fe-Mo co)" from Azotobacter Vinelandii. ${ }^{1}$ This cofactor was reported to contain one $\mathrm{Mo}$, eight $\mathrm{Fe}$, six labile inorganic $\mathrm{S}$, and a polypeptide. The EXAFS investigation of "Fe-Mo co" indicated the presence of a mixed MoFe-sulfur cluster at the molybdenum site. This cofactor has catalytic activity (which is $c a$. $8 \%$ on that of native nitrogenase) in the selective reduction of acetylene to ethylene with $\mathrm{NaBH}_{4}$ as a reducing agent. ${ }^{2}$ On the other hand, a series of the investigations on nitrogenase model reactions reported by Schrauzer and others revealed that dioxodimolybdenum complexes containing L-cysteine and other compounds bearing thiolato groups as ligands had catalytic activities for the reduction of dinitrogen as well as compounds such as acetylene, etc. ${ }^{3}$ Various other modifications of these catalyst systems have also been achieved. ${ }^{4}$ Otsuka et al. reported recently that dioxo-dimolybdenum complexes having a di- $\mu$-sulfido bridge were excellent catalysts for the reduction and reductive cleavage of azobenzene with $\mathrm{NaBH}_{4} \cdot{ }^{5}$ It is important that the "Fe-Mo co" be surrounded by polypeptides con- taining probably L-cysteine residues which stabilize the active sites of nitrogenase. Elucidation of the role of polypeptide in enhancing the catalysis seems vital for understanding the "nitrogenase action." We have investigated the nitrogenase model reaction, employing the di- $\mu$-sulfido-bis[thioxanthato(oxo)molybdenum] complex supported on synthetic copolypeptides as catalysts. Azobenzene and phenylacetylene were chosen as substrates and the ferredoxin model complex was used as an electron-transfer agent.

\section{EXPERIMENTAL}

\section{Reagents}

All amino acids were purchased from the Peptide Institute. All solvents such as tetrahydrofuran, hexane, ethyl ether, and petroleum ether were distilled from sodium benzophenone ketyl or potassium-sodium alloy under argon atmosphere.

\section{Spectroscopic Measurements}

Visible and ultraviolet (UV) spectra were taken with a JASCO UVIDEC 5A spectrophotometer at room temperature. Infrared (IR) spectra were run as $\mathrm{KBr}$ pellets using a JASCO MODEL DS-402G 
recording spectrometer. Nuclear magnetic resonance (NMR) spectra were measured with a Varian $\mathrm{XL}-100 \mathrm{~A}$, using tetramethylsilane as the standard.

\section{Di- $\mu$-sulfido-bis[neopentylxanthato (oxo)molybde- $\operatorname{num}(V)](\mathbf{1})$}

Hydrogen sulfide was passed through a solution of $\mathrm{Na}_{2} \mathrm{MoO}_{4} \cdot 2 \mathrm{H}_{2} \mathrm{O}(24 \mathrm{mmol})$ in water $(70 \mathrm{ml})$ until the color of the solution turned deep-red. Then, a solution of potassium 2,2-dimethyl-1-propylxanthate $(24 \mathrm{mmol})$ in water $(50 \mathrm{ml})$ was mixed with this solution, and the $\mathrm{pH}$ of the resulting solution was lowered to 8 by the addition of aq. $2 \mathrm{~N}$ $\mathrm{HCl}$ to give brown precipitates. The recrystallization of the product from a mixture of chloroform and hexane $(1: 4)$ gave brown crystals having the title complex. Anal. Calcd for $\mathrm{C}_{12} \mathrm{H}_{22} \mathrm{O}_{4} \mathrm{~S}_{6} \mathrm{Mo}_{2}$ : C, $23.45 \%$; $\mathrm{H}, 3.61 \%$. Found: $\mathrm{C}, 22.76 \%$; $\mathrm{H}, 3.65 \%$. Infrared spectrum $(\mathrm{KBr}): 1062,1022 \mathrm{~cm}^{-1}(\mathrm{~m}$, $v \mathrm{C}=\mathrm{S}) ; 950,930 \mathrm{~cm}^{-1}(\mathrm{~s}, v \mathrm{Mo}=\mathrm{O}) ; 472 \mathrm{~cm}^{-1}(\mathrm{~m}$, $v$ Mo-S). Absorption spectrum $\left(\mathrm{CHCl}_{3}\right): 275 \mathrm{~nm}$ $(\varepsilon=13400), 326 \mathrm{~nm}(\varepsilon=6990), 385 \mathrm{~nm}(\varepsilon=2140)$.

\section{Di- $\mu$-sulfido-bis[n-amylthioxanthato (oxo) molybde- $\operatorname{num}(V)](3)$}

This compound was prepared using sodium $n$ amylthioxanthate as a starting material by the method of Zubieta. ${ }^{6}$ The product, brown crystals. Anal. Calcd for $\mathrm{C}_{12} \mathrm{H}_{22} \mathrm{O}_{2} \mathrm{~S}_{8} \mathrm{Mo}_{2}: \mathrm{C}, 22.28 \% ; \mathrm{H}$, $3.44 \%$. Found: C, $22.08 \% ; \mathrm{H}, 3.49 \%$. Infrared spectrum (KBr): $1010 \mathrm{~cm}^{-1}(\mathrm{~m}, \nu \mathrm{C}=\mathrm{S}) ; 972,942$ $\mathrm{cm}^{-1}(\mathrm{~s}, v \mathrm{Mo}=\mathrm{O}) ; 818 \mathrm{~cm}^{-1}$ (s, $\left.v \mathrm{C}-\mathrm{S}\right) ; 468,363$ $\mathrm{cm}^{-1}$ (m, $\left.v \mathrm{Mo}-\mathrm{S}\right)$. Absorption spectrum $\left(\mathrm{CHCl}_{3}\right)$ : $325 \mathrm{~nm}(\varepsilon=17500), 403 \mathrm{~nm}(\varepsilon=1725)$.

\section{Copolypeptide (4) Consisted of $\gamma$-Benzyl L-glutamate and S-Benzylthio-methyl-L-cysteine \\ $N$-Carboxy anhydrides (NCAs) of $\gamma$-benzyl L-} glutamate and $S$-benzylthiomethyl-L-cysteine in ethyl acetate were mixed in an ampoule under nitrogen atmosphere. Ethyl acetate was removed under reduced pressure and the residue was dissolved in dimethylformamide (DMF) which had been previously distilled and degassed. The copolymerization of both NCAs with benzylamine as an initiator was allowed to stand for $48 \mathrm{~h}$ at $25 \pm 0.2^{\circ} \mathrm{C}$ under a dry nitrogen atmosphere. The copolypeptide was obtained by the addition of ether to the solution, and reprecipitated from DMF and ether. Cysteine residues in the copolypeptide obtained was analyzed quantitatively by ${ }^{1} \mathrm{H}-\mathrm{NMR}$ spectrum. The molecular weight of the polypeptides was determined by gel-permeation chromatography (Shimadzu 830; column, Shimadzu HSG 40). Two kinds of copolypeptides were obtained by the above procedure.

\section{S-Deblocked Copolypeptide (5)}

Copolypeptide $(1.0 \mathrm{~g})$ was dissolved in dichloroacetic acid $(12.5 \mathrm{ml})$, and a partial suspension of a certain amount of mercuric acetate (four times equivalents of cysteine residues) in water was added with stirring under nitrogen atmosphere to give a clear solution. After one-hour of stirring at room temperature, 1,2-ethanedithiol (2.5 times $\mathrm{mol}$ of mercuric acetate) was added so as to precipitate mercuric sulfide. After removal of the mercuric sulfide by filtration, an $S$-deblocked copolypeptide was obtained as a precipitate by the addition of ether previously degassed in vacuo. The resulting copolypeptide was dried in vacuo (yield $50 \%$ ).

\section{Copolypeptide-Molybdenum Complex (6)}

The molybdenum complex 1 (two times equivalents of cysteine residues) was added to a THF solution $(90 \mathrm{ml})$ of copolypeptide $(1.0 \mathrm{~g})$ in an ampoule under a dry argon atmosphere. The mixture was allowed to stand at $50^{\circ} \mathrm{C}$ for $62 \mathrm{~h}$. The reaction mixture was concentrated to one-third of its original volume by the removal of solvent under reduced pressure and was added dropwise to a large amount of methanol with stirring. The precipitates, copolypeptide-molybdenum complexes were separated by filtration and washed with methanol several times to remove any of the unreacted molybdenum complexes. The molybdenum content in the copolypeptide-molybdenum complexes was analyzed by a Japan JARREL-ASH atomic absorption photometry AA-1 in aq. $\mathrm{HClO}_{4}$. The product was separated into two fractions, the soluble and insoluble portions in THF.

\section{Substitution Reaction of Molybdenum Complex 1 with $n$-Amylmercaptan}

To $1(3.9 \mathrm{mmol})$ in THF $(200 \mathrm{ml})$ was added $n$ amylmercaptan $(3.9 \mathrm{mmol})$ with stirring under argon atmosphere. The solution was shaken at $50^{\circ} \mathrm{C}$ for $62 \mathrm{~h}$, and then concentrated to one-fourth of its original volume by distillation of the solvent under reduced pressure. All the molybdenum complexes 
are precipitated by the addition of hexane to the reaction mixture, and separated by filtration and dried in vacuo. The degree of substitution of the neopentoxy group by the $n$-amylthio group was $63.4 \%$, as determined by ${ }^{1} \mathrm{H}$ NMR spectroscopy.

\section{Reduction of Phenylacetylene with Copolypeptide- Molybdenum Complexes}

The copolypeptide-molybdenum complex $(0.05$ mmol to molybdenum) and ferredoxin model comound, $\quad\left[\mathrm{Fe}_{4} \mathrm{~S}_{4}(\mathrm{SPh})_{4}\right]^{2-}\left[\mathrm{N} n-\mathrm{Bu}_{4}\right]_{2}^{2+}, \quad(0.037$ mmol) prepared by the method of $\mathrm{Holm}^{7}$ were mixed in a mixture of ethanol $(3.5 \mathrm{ml})$, THF $(6.0 \mathrm{ml})$, and methanol $(7.0 \mathrm{ml})$ under nitrogen atmosphere. Then sodium borohydride $(25 \mathrm{mmol})$ as a reducing agent was added to this catalyst solution. After the evolution of hydrogen gas ceased, phenylacetylene $(4.9 \mathrm{mmol})$ was added to the catalyst solution and the reaction vessel was shaken in a water bath kept at $30^{\circ} \mathrm{C}$ for $24 \mathrm{~h}$. After hexane was added to the reaction mixture to precipitate the catalyst, the clear upper layer was evaporated under reduced pressure, and all the distillate in the trap cooled at $-78^{\circ} \mathrm{C}$ was analyzed by gas-liquid chromatography (GLC) using toluene as a reference substance. The column packing material was silicon DC $550,15 \%$ at $70^{\circ} \mathrm{C}$ and apiezone grease $10 \%$ at $100^{\circ} \mathrm{C}$.

\section{Reduction of Azobenzene with Copolypeptide- Molybdenum Complexes}

The reaction procedure was the same as in the case of the reduction of phenylacetylene except for the use of azobenzene $(5.0 \mathrm{mmol})$ instead of phenylacetylene. Ether was added to the reaction mixture and the upper layer was separated and distilled under reduced pressure. Aniline in the distillates was determined quantitatively by gas chromatography using toluene as a reference substance. Hydrazobenzene remaining in the residue was determined quantitatively by IR spectrum $\left(755 \mathrm{~cm}^{-1}\right.$ $\left.\delta-\mathrm{C}_{6} \mathrm{H}_{5}\right)$.

\section{RESULTS AND DISCUSSION}

\section{Preparative Aspects}

The catalytically active molybdenum complex serving as a nitrogenase model must be designed to allow for a ready reaction with the cysteine thiol group and to maintain its activity after attachment

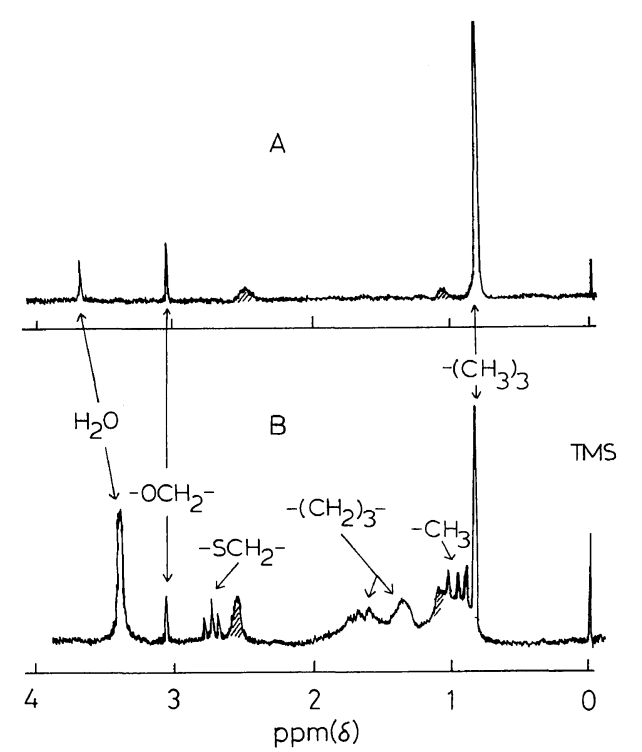

Figure 1. ${ }^{1} \mathrm{H}-\mathrm{NMR}$ spectra in dimethyl sulfoxide- $d_{6}$ of (A) $\mathrm{Mo}_{2} \mathrm{O}_{2} \mathrm{~S}_{2}\left(\mathrm{~S}_{2} \mathrm{CO}-\mathrm{Neopentyl}\right)_{2}$, and (B) the reaction product of 1 with $n$-amylmercaptan.

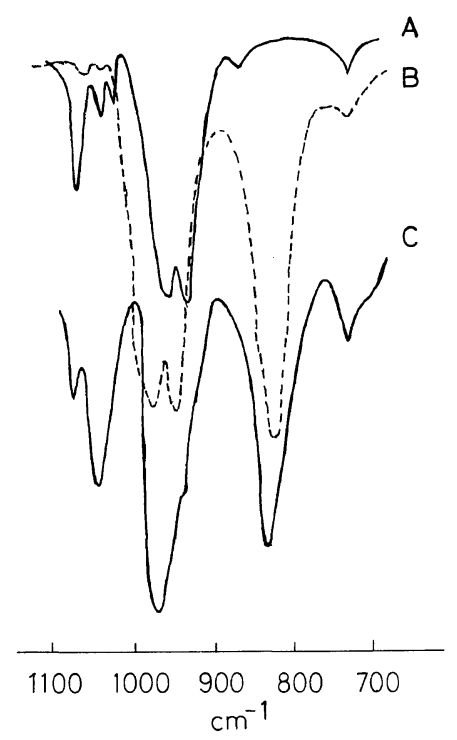

Figure 2. IR spectra of (A) $\mathrm{Mo}_{2} \mathrm{O}_{2} \mathrm{~S}_{2}\left(\mathrm{~S}_{2} \mathrm{CO}-\mathrm{Neo}-\right.$ pentyl $)_{2}$, (B) $\mathrm{Mo}_{2} \mathrm{O}_{2} \mathrm{~S}_{2}\left(\mathrm{~S}_{2} \mathrm{CS}-n \text {-Amyl }\right)_{2}$, and (C) the reaction product of $\mathbf{1}$ with $n$-amylmercaptan.

onto a cysteine-containing polypeptide. Thus, di- $\mu$ sulfido-bis[neopentylxantho(oxo)molybdenum(V)] (1) was chosen and the following model reaction of 1 was performed with a simple organic thiol compound. The ligand substitution reaction of $\mathbf{1}$ was 
Table I. Selected infrared frequencies in $\mathrm{cm}^{-1}$

\begin{tabular}{cccc}
\hline $\mathrm{Mo}_{2} \mathrm{O}_{2} \mathrm{~S}_{2}\left(\mathrm{~S}_{2} \mathrm{CO}-\mathrm{Neopentyl}\right)_{2}$ & $\mathrm{Mo}_{2} \mathrm{O}_{2} \mathrm{~S}_{2}\left(\mathrm{~S}_{2} \mathrm{CS}-n \text {-Amyl }\right)_{2}$ & Reaction product & Assignments \\
\hline $1062(\mathrm{~s}), 1022(\mathrm{w})$ & $1010(\mathrm{sh})$ & $1050(\mathrm{~s})$ & $v(\mathrm{C}=\mathrm{S})$ \\
$950(\mathrm{vs})$ & $972(\mathrm{vs})$ & $970(\mathrm{vs})$ & $v(\mathrm{Mo}=\mathrm{O})$ \\
$930(\mathrm{~s})$ & $942(\mathrm{~s})$ & $940(\mathrm{~s})$ & $v(\mathrm{C}-\mathrm{S})$ \\
& $818(\mathrm{vs})$ & $829(\mathrm{vs})$ & $v(\mathrm{Mo}-\mathrm{S})$ \\
\hline
\end{tabular}

Table II. Characteristics of copolypeptides and their molybdenum complexes

\begin{tabular}{|c|c|c|c|c|}
\hline \multirow{3}{*}{ Complexes } & \multicolumn{2}{|c|}{ Copolypeptides } & \multicolumn{2}{|c|}{ Molybdenum complexes soluble in $\mathrm{THF}^{\mathrm{c}}$} \\
\hline & $\begin{array}{l}\text { Content of cysteine } \\
\text { residues }^{\mathrm{a}}\end{array}$ & $\begin{array}{l}\text { Degree of polymerization } \\
\text { of copolypeptides }\end{array}$ & Yield & Ratio of $\mathrm{Mo} / \mathrm{Cys}^{\mathrm{d}}$ \\
\hline & $\%$ & & & \\
\hline $6 \mathrm{~A}$ & 13.3 & $18-24$ & 72 & 0.69 \\
\hline $6 \mathrm{~B}$ & 19.6 & $17-46$ & 42 & 0.29 \\
\hline
\end{tabular}

a The cysteine residues were analyzed quantitatively by ${ }^{1} \mathrm{H}-\mathrm{NMR}$ spectrum.

b The molecular weights of the copolypeptides were derermined by gel-permeation chromatography.

c The complex insoluble in THF was identified as cross-linked complex.

d The molybdenum content was determined by atomic-absorption spectral analysis.

conducted with $n$-amylmercaptan in THF at $50^{\circ} \mathrm{C}$ for $62 \mathrm{~h} .{ }^{1} \mathrm{H}$ NMR spectra of 1 and the ligandsubstitution reaction product are given in Figure 1. The NMR spectra show the presence of a neopentyl group and an $n$-amyl group in the product. The infrared spectra of 1 , the reaction product and $\mathrm{Mo}_{2} \mathrm{O}_{2} \mathrm{~S}_{2}\left(\mathrm{~S}_{2} \mathrm{CS} n \text {-Amyl }\right)_{2}$ (3) prepared from the reaction of $\left[\mathrm{S}_{2} \mathrm{CSn}-\mathrm{Amyl}\right]^{-}$with $\left[\mathrm{Mo}_{2} \mathrm{O}_{2} \mathrm{~S}_{2}\right]^{2+}$ are shown in Figure 2. Although there has been some controversy in regard to the assignment of infrared

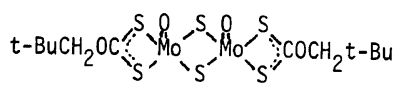

(1)

$$
\begin{aligned}
& +{ }_{n}-\mathrm{C}_{5} \mathrm{H}_{11} \mathrm{SH} \longrightarrow \\
& \mathrm{Mo}_{2} \mathrm{O}_{2} \mathrm{~S}_{2}\left(\mathrm{~S}_{2} \mathrm{CO}-\mathrm{Neopenty1}\right)\left(\mathrm{S}_{2} \mathrm{CS}-n-\text { Amy } 1\right) \\
& +\mathrm{Mo}_{2} \mathrm{O}_{2} \mathrm{~S}_{2}\left(\mathrm{~S}_{2} \mathrm{CS}-n-\text { Amy }\right)_{2}+\mathrm{t}-\mathrm{BuCH}_{2} \mathrm{OH}
\end{aligned}
$$

(3)

absorption bands to molybdenum-oxygen stretching vibrations of binuclear oxo-complexes of molyb- denum (V) and (VI) ${ }^{8}$ comparative spectral studies of these ${ }^{16} \mathrm{O}$ - and ${ }^{18} \mathrm{O}$-substituted oxomolybdenum complexes have made these assignments more reliable. ${ }^{9}$ The assignments of the infrared spectra of molybdenum complexes 1,3 , and the reaction product are shown in Table I. These assignments agree with that of $\mathrm{Mo}_{2} \mathrm{O}_{4}\left(\mathrm{~S}_{2} \mathrm{CNR}_{2}\right)(\mathrm{R}=$ methyl, ethyl, etc. $){ }^{10}$ and $\mathrm{Mo}_{2} \mathrm{O}_{4}\left(\mathrm{~S}_{2} \mathrm{CSR}\right)_{2}(\mathrm{R}=i$-Pr, and $t$-Bu). ${ }^{6}$ It is obvious that the reaction product contains the C-S-( $n$-Amyl) group from the observation of characteristic absorption at $829 \mathrm{~cm}^{-1}$. The fact that the infrared spectrum of the reaction product is not coincident with the overlapped spectrum of two materials of $\mathbf{1}$ and $\mathbf{3}$ can be considered to be a results of the production of the compound 2 .

The copolypeptides of $S$-benzylthiometyl-Lcysteine and $\gamma$-benzyl L-glutamate were prepared from the $N$-carboxy anhydride of the corresponding amino acids (Cys and Glu NCAs) in dimethylformamide (DMF) at $25^{\circ} \mathrm{C}$. We chose the Glu NCA as a comonomer for increasing the solubility of the copolypeptide. Two samples of copolypeptides were prepared by variation in the monomer ratio of Cys 
NCA/Glu NCA. The characteristics of the copolypeptides are shown in Table II.

The copolypeptides and molybdenum complex 1 were mixed under conditions similar to those for the ligand-substitution reaction. Insoluble blackish precipitates were formed during this reaction. It may be considered that the products insoluble in benzene, dichloromethane, chloroform, and THF were crosslinked copolypeptide complexes due to bifunctional character of 1 . The soluble part of the reaction product was isolated as a precipitate by the addition of methanol to the solution. The amount of the insoluble part increased with an increase in the cysteine content of the copolypeptide. The ${ }^{1} \mathrm{H}$ NMR spectra of copolypeptide and its molybdenum complex are shown in Figure 3. Two singlet absorptions were observed for the methylene protons of the $\mathrm{S}-\mathrm{CH}_{2}-\mathrm{S}(\delta 3.6 \mathrm{ppm})$ and the $\mathrm{Ph}-\mathrm{CH}_{2}-\mathrm{S}$ $(\delta 4.7 \mathrm{ppm})$ groups in the copolypeptide; these were absent in the spectrum of the polypeptidemolybdenum complex. A doublet for the methylene protons of the cysteine residues at $\delta 3.4 \mathrm{ppm}$ shifted to $\delta 3.2 \mathrm{ppm}$ when the thiolato groups of the cysteine residues were bound to the xanthate groups of the molybdenum complex. Several singlet absorptions for the methyl protons of neopentyl group in the polypeptide-molybdenum complex were observed at $\delta 0.8-1.2 \mathrm{ppm}$. This observation may be explained as due to the existence of various

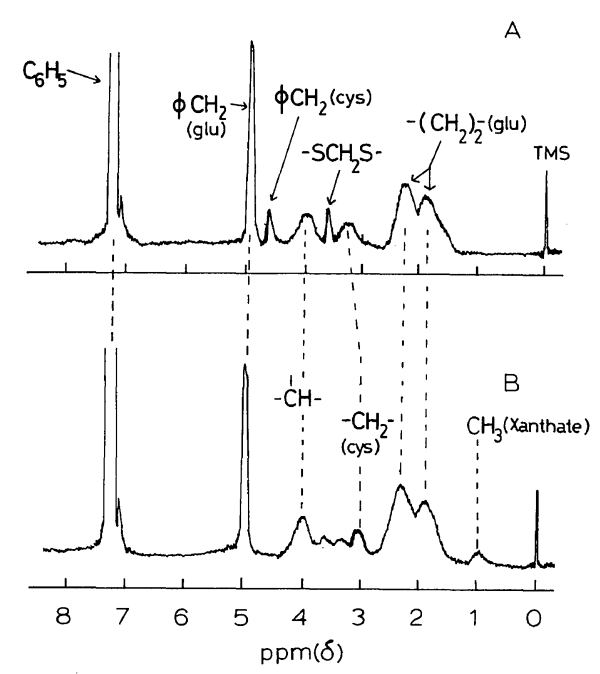

Figure 3. ${ }^{1} \mathrm{H}-\mathrm{NMR}$ spectra in $\mathrm{CDCl}_{3}-\mathrm{CF}_{3} \mathrm{CO}_{2} \mathrm{D}(1: 1)$ of (A) the copolypeptide 6A and (B) its molybdenum complex. neopentyl groups under magnetically different circumstance because of the random sequence of cysteine residues in the copolypeptide.

The infrared spectra of copolypeptide (3) and the copolypeptide-molybdenum complex (5) are shown in Figure 4. The copolypeptide-molybdenum complex had absorptions at 930 and $950 \mathrm{~cm}^{-1}$ assignable to the $\mathrm{Mo}=\mathrm{O}$ stretching which were also found for 1 . The Mo-S stretching absorption in 6 could

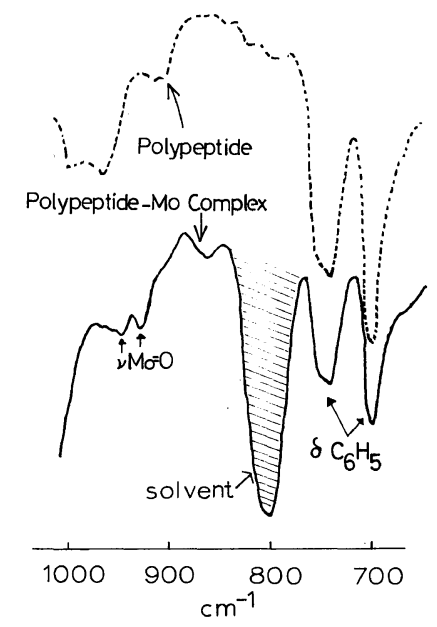

Figure 4. IR spectra of (A) the copolypeptide $6 \mathrm{~A}$ and (B) its molybdenum complex.

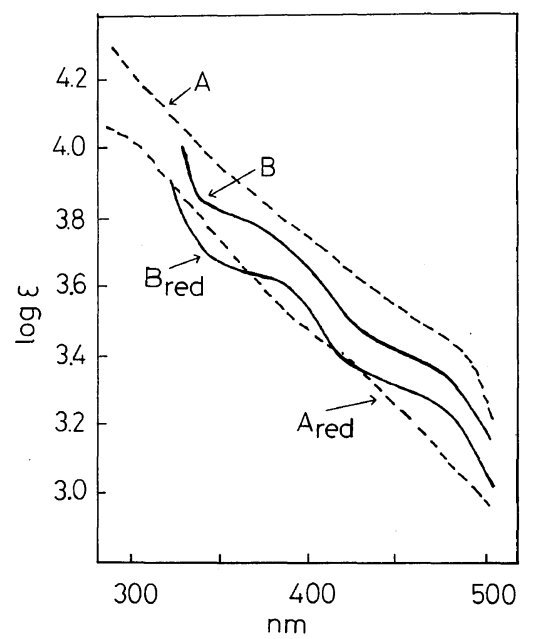

Figure 5. Absorption spectra in DMF of (A) $\mathrm{Mo}_{2} \mathrm{O}_{2} \mathrm{~S}_{2}\left(\mathrm{~S}_{2} \mathrm{CO}-\mathrm{Neopentyl}\right)_{2}$, (A) red $\mathrm{Mo}_{2} \mathrm{O}_{2} \mathrm{~S}_{2}\left(\mathrm{~S}_{2} \mathrm{CO}-\right.$ Neopentyl $)_{2}$ in the reduced state, (B) the copolypeptide $6 \mathrm{~A}-\mathrm{Mo}_{2} \mathrm{O}_{2} \mathrm{~S}_{2}\left(\mathrm{~S}_{2} \mathrm{CO}-\mathrm{Neopentyl}\right)_{2}$ complex, and (B) the complex (B) in the reduced state. Reducing agent was $\mathrm{NaBH}_{4}$. 


\section{N. Oguni, S. Shimazu, and A. Nakamura}

not clearly be observed because of weak intensity and overlap with the stronger absorptions of the copolypeptides. The other absorptions of 6 were the same as that of copolypeptide.

Unreduced molybdenum complex $\mathbf{1}$ had an electronic absorption at $c a .470 \mathrm{~nm}(\log \varepsilon=3.51)$ as a shoulder and unreduced copolypeptidemolybdenum complex also had an absorption at $c a$. $480 \mathrm{~nm}(\log \varepsilon=3.36)$ as a shoulder (Figure 5). Both peaks may be due to the chromophore of $\mathrm{MoS}_{2} \mathrm{Mo}$. The complexes, $\left[\mathrm{Mo}_{2} \mathrm{O}_{2} \mathrm{~S}_{2} \mathrm{~L}_{2}\right](\mathrm{L}=\mathrm{L}$-cysteine or $\mathrm{L}$ cysteine methyl ester) in which bridging oxygen $(\mu$ oxo) had been replaced by sulfur were reported to have additional peaks or shoulders in the $410-500$ $\mathrm{nm}$ region. The position of these peaks bathochromically shifts
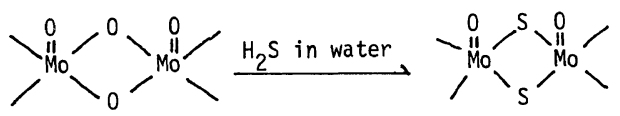

additional peaks at $410-500 \mathrm{~nm}$

as the $\mathrm{S}$; Mo ratio increases. ${ }^{11}$ There were few differences in the absorption patterns between 1 and 6. Hence it may be concluded that the $\mathrm{MoS}_{2} \mathrm{Mo}$ group were bound mostly to the cysteine residues in copolypeptide through the xanthate groups. In both complexes, the absorption spectra did not remar kably change when the complexes were reduced by $\mathrm{NaBH}_{4}$ in DMF-MeOH. Absorption peaks due to the d-d transition were not clearly detected, possibly because these peaks were covered by the charge-transfer bands. Mitchell and his coworkers were also unable to detect any d-d transitions in the spectra of $\mathrm{Mo}_{2} \mathrm{O}_{4} \mathrm{~L}_{2}$-type complexes for similar reasons. ${ }^{11}$

\section{Catalytic Activity of the Copolypeptide-Molyb- denum Complex}

In this work, we used phenylacetylene and azobenzene as substrates which were more easily reduced than dinitrogen. The results obtained are shown in Table III. In the presence of a catalytic system of copolypeptide-molybdenum complex, the reduction of phenylacetylene proceeded very slowly to give styrene. The ferredoxin model complex also showed weak activity. In contrast to this, in the catalytic system prepared by mixing the copolypeptide-molybdenum complex and ferredoxin model complex, styrene was produced about 20 times as much as that in the respective single component systems (eq 1). Furthermore, only a few percentage of the phenylacetyelene was reduced to ethylbenzene in this system. Consequently, such a remarkably higher activity in this mixed system than in that of the unmixed systems is due to certain types of interactions between the molybdenum complex and the ferredoxin model complex. ${ }^{12}$ That the mixed system of the copolypeptide-molybdenum complex and ferredoxin model complex had the highest catalytic activity among the mixed systems is

Table III. Reduction of phenylacetylene and azobenzene with $\mathrm{NaBH}_{4}$ by the catalysis of a mixture of copolypeptide-molybdenum complexes and $\left[\mathrm{Fe}_{4} \mathrm{~S}_{4}(\mathrm{SPh})_{4}\right]^{2-}$

(The value of substrate consumption is based on $0.1 \mathrm{mmol}$ of $\mathrm{Mo}$.) ${ }^{\mathrm{a}}$

\begin{tabular}{|c|c|c|c|c|c|}
\hline \multirow{2}{*}{ Catalyst system } & \multicolumn{3}{|c|}{ Products from $\mathrm{PhC} \equiv \mathrm{CH}$ (in $\mathrm{mmol}$ ) } & \multicolumn{2}{|c|}{$\begin{array}{l}\text { Products from } \mathrm{PhN}=\mathrm{NPh} \\
\text { (in mmol) }\end{array}$} \\
\hline & $\mathrm{PhCH}=\mathrm{CH}_{2}$ & $\mathrm{PhCH}_{2} \mathrm{CH}_{3}$ & $\begin{array}{l}\text { Reduced dimer } \\
\text { and polymer }\end{array}$ & $\mathrm{PhNHNHPh}$ & $\mathrm{PhNH}_{2}$ \\
\hline $6 \mathrm{~A}$ & 1.43 & 0 & trace & 0 & 0 \\
\hline$\left[\mathrm{Fe}_{4} \mathrm{~S}_{4}(\mathrm{SPh})_{4}\right]^{2-}$ & 0.11 & 0 & 0.02 & 0.24 & 0.21 \\
\hline $\mathrm{Mo}_{2} \mathrm{O}_{2} \mathrm{~S}_{2}\left(\mathrm{~S}_{2} \mathrm{CO}-\mathrm{Neopentyl}\right)_{2}$ & & & & & \\
\hline$+\left[\mathrm{Fe}_{4} \mathrm{~S}_{4}(\mathrm{SPh})_{4}\right]^{2-}$ & 3.61 & 0.34 & 0.73 & 0.51 & 0.39 \\
\hline $6 \mathrm{~A}+\left[\mathrm{Fe}_{4} \mathrm{~S}_{4}(\mathrm{SPh})_{4}\right]^{2-}$ & 24.0 & 0.66 & 4.83 & 12.1 & 5.24 \\
\hline $6 \mathrm{~B}+\left[\mathrm{Fe}_{4} \mathrm{~S}_{4}(\mathrm{SPh})_{4}\right]^{2-}$ & 21.9 & 0.34 & 1.78 & - & - \\
\hline
\end{tabular}

a Conditions: [Substrate], $4.9 \mathrm{mmol}$; $\left[\mathrm{NaBH}_{4}\right], 24.5 \mathrm{mmol}$; time, $7 \mathrm{~h}$; temperature, $30^{\circ} \mathrm{C}$; solvent, EtOH-THF-MeOH (3.5:6:7 for $\mathrm{PhC} \equiv \mathrm{CH}, 3: 8: 6$ for $\mathrm{PhN}=\mathrm{NPh}$ ); ratio of $\mathrm{Mo}-\mathrm{Fe}, 1: 3$; amount of catalyst (mmol of $\mathrm{Mo}$ ), $6 \mathrm{~A}$, and $6 \mathrm{~A}$ $+\left[\mathrm{Fe}_{4} \mathrm{~S}_{4}(\mathrm{SPh})_{4}\right]^{2-} 0.78 \times 10^{-2},\left[\mathrm{Fe}_{4} \mathrm{~S}_{4}(\mathrm{SPh})_{4}\right]^{2-} 0.14, \mathrm{Mo}_{2} \mathrm{O}_{2} \mathrm{~S}_{2}\left(\mathrm{~S}_{2} \mathrm{CO}-\text { Neopentyl }\right)_{2}+\left[\mathrm{Fe}_{4} \mathrm{~S}_{4}(\mathrm{SPh})_{4}\right]^{2-} 0.49 \times 10^{-1}$, $6 \mathrm{~B}+\left[\mathrm{Fe}_{4} \mathrm{~S}_{4}(\mathrm{SPh})_{4}\right]^{2-} 0.7 \times 10^{-2}$. 
remarkable. In the reduction and reductive cleavage of azobenzene (eq 2), a similar tendency was observed. Because the aggregation of reduced molybdenum species is prevented, the catalytic activity is expected to increase with an increase in

$$
\begin{gathered}
\mathrm{PhC} \equiv \mathrm{CH} \longrightarrow \mathrm{PhCH}=\mathrm{CH}_{2}+\mathrm{PhCH}_{2} \mathrm{CH}_{3} \\
\mathrm{PhN}=\mathrm{NPh} \longrightarrow \mathrm{PhNHNHPh}+\mathrm{PhNH}_{2}
\end{gathered}
$$

the degree of dispersion (site isolation). These copolypeptide-molybdenum complexes scarcely exhibit any CD extrema in the range of $400-$ $700 \mathrm{~nm}$ in a DMF solution, indicating that dorbitals of molybdenum are not affected by chirality in the cysteine residues. The suggested structure of copolypeptide-molybdenum complex is given as follows,

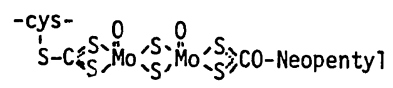

\section{Mechanism of Reduction}

A plausible mechanism for the reduction is shown in Figure 6. In natural nitrogenase, the oxidation number of molybdenum in the reduced state, $\left[\mathrm{Mo}_{\text {red }}\right]$, is still ambiguous. Stiefel proposed that Mo(II) should still be considered as a possibility for the lower redox state of molybdenum in nitrogenase. ${ }^{13}$ Schrauzer et al. have also proposed a mechanism in which the reduced molybdenum species reacts with acetylene to give ethylene by hydrolysis. ${ }^{14}$ The reduced molybdenum species is considered to serve as a two-electron reducing agent. It was reported by Schultz that the electrolytic reduction of a $\mathrm{Mo}(\mathrm{V})$-cysteine complex in

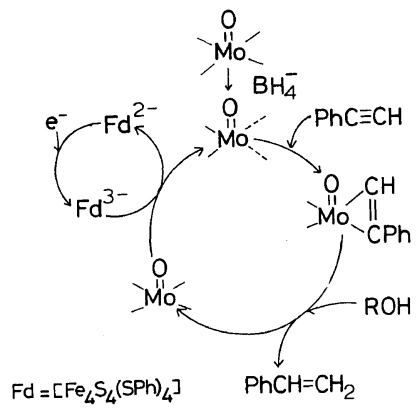

Figure 6. Proposed mechanism for the reduction of phenylacetylene with the molybdenum complex. the presence of acetylene gave a Mo(III) species and ethylene was produced by the protonation of a Mo(III)-acetylene complex formed in the electrolytic reduction. ${ }^{15} \mathrm{~A} \mathrm{Mo}(\mathrm{V})$ species was probably reduced to a Mo(II) or $\mathrm{Mo}$ (III) species by $\mathrm{NaBH}_{4}$ which readily interacts with phenylacetylene or azobenzene to give a side-on $\left(\eta^{2}\right)$ coordinated intermediate. These species are presumably protolyzed by alcohol and afford styrene or hydrazobenzene; molybdenum is oxidized to $\mathrm{Mo}(\mathrm{V})$, as was already proposed in our previous paper. ${ }^{16}$

\section{REFERENCES}

1. V. K. Shah and W. J. Brill, Proc. Natl. Acad. Sci., U.S.A., 74, 3249 (1977); "Proceedings of the Steenbock-Kettering International Symposium on Nitrogen Fixation," Steenbock, Ohio, June 12-16, 1978.

2. V. K. Shah, J. R. Chisnell, and W. J. Brill, Biochem. Biophys. Res. Commun., 81, 232 (1978).

3. G. N. Schrauzer, Angew. Chem. Int. Ed., 14, 514 (1975).

4. B. J. Weathers, J. H. Grate, N. A. Strampach, and G. N. Schrauzer, J. Am. Chem. Soc., 101, 925 (1979).

5. A. Nakamura, M. Nakayama, K. Sugihashi, and S. Otsuka, Inorg. Chem., 18, 394 (1979).

6. J. Hyde, K. Venkatasubramanian, and J. Zubieta, Inorg. Chem., 17, 414 (1978).

7. B. A. Averill, T. Herskovitz, R. H. Holm, and J. A. Ibers, J. Am. Chem. Soc., 95, 3523 (1973).

8. F. W. Moore and M. L. Larson, Inorg. Chem., 6, 998 (1976); R. N. Jowitt and P. C. H. Mitchell, J. Chem. Soc., Sect. A, 2632 (1969); 1702 (1970).

9. W. E. Newton and J. W. McDonald, J. Less Common Met., 54, 51 (1977).

10. W. E. Newton, J. L. Corbin, D. C. Bravard, J. E. Searles, and J. W. McDonald, Inorg. Chem., 13, 1100 (1974).

11. A. Kay and P. C. H. Mitchell, J. Chem. Soc., Sect. A, 241 (1970).

12. A example of the reaction of molybdenum complex with ferredoxin model complex is shown in S. Otsuka and M. Kamata, "Molybdenum Chemistry of Biological Significance" W. E. Newton and S. Otsuka, Ed., "Proceedings of the International Symposium" Lake Biwa, Kyoto, April 1979, Plenum Press, New York, N.Y., 1979, p 229.

13. E. I. Stiefel, Prog. Inorg. Chem., 22, 1 (1977).

14. G. N. Schrauzer and P. A. Doemeny, J. Am. Chem. Soc., 93, 1608 (1971).

15. D. A. Ledwith and F. A. Schultz, J. Am. Chem. Soc., 97, 6591 (1975).

16. A. Nakamura, M. Kamata, K. Sugihashi, and S. Otsuka, J. Mol. Catal., 8, 353 (1980). 